\title{
Analysis of Technical Efficiency of Small Holder Maize Growing Farmers of Horo Guduru Wollega Zone, Ethiopia: A Stochastic Frontier Approach
}

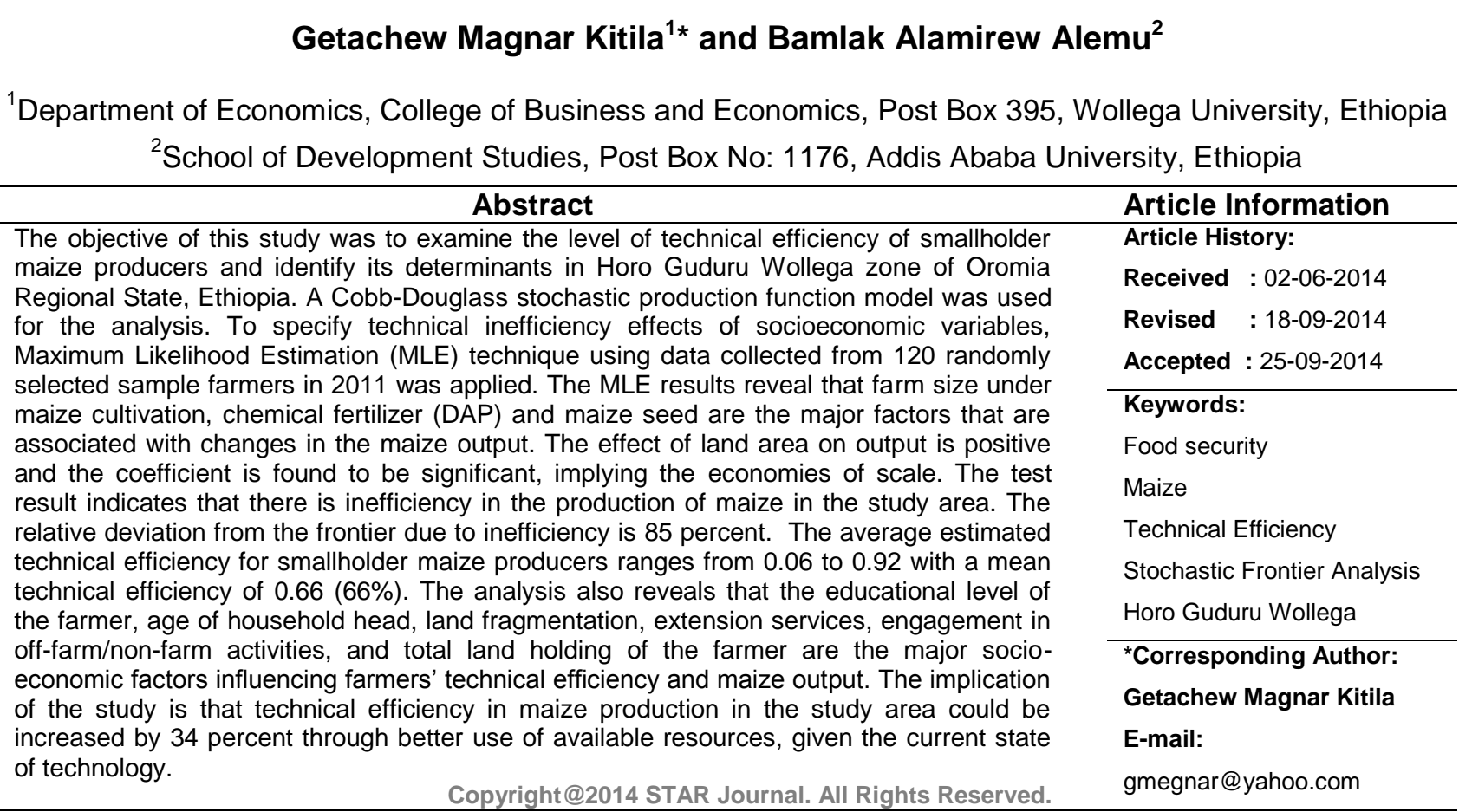

\section{INTRODUCTION}

The Comprehensive African Agriculture Development Program (CAADP) of the New Partnership for Africa's Development (NEPAD) has worked towards ending hunger and poverty across Africa by improving agricultural productivity. The CAADP Pillar 1 Framework on Sustainable Land and Water Management (SLWM) aims to extend the area under sustainable land and water management throughout sub-Saharan Africa. It is one the entry points where member countries can investments in sustainable agriculture and food production systems to unlock the full potential of African Agriculture. With sustained investments in agriculture, African could even feed the world. Likewise, many regional organizations across Africa have launched programs to support the achievement of CAADP Pillar 1. Examples include: SADC Regional Indicative Strategic Development Program (RISDP) (SADC, 2003), aiming to double the area under irrigated agriculture by 2015 , and increasing agricultural growth to an average annual growth rate of $6 \%$ by raising investments to $10 \%$ of national expenditure. The underlying goal is evidence- and outcome-based planning and implementation of agriculture sector policies and investment strategies to realize CAADP targets and commitments to sustainably end hunger and poverty across Africa and contribute towards achieving the
Millennium Development Goals on ending hunger and halving extreme poverty by 2015, and contributing towards the post 2015 Social Development Goals.

To that end, the Framework seeks to promote partnerships between international, regional, national, provincial, and local government and community level stakeholders with the goal of enhancing the productivity of land and water resources in Africa. As African agriculture make a sterling contribution in most African economies, its success is critical for enhancing food security. African leaders therefore identified agriculture as a key intervention area in achieving the NEPAD vision and rolling out the CAADP.

Within agriculture the key food security crops prioritized are maize, wheat, sorghum, rice, and cassava, for instance by the SADC. Whereas, maize, sugarcane, soya, and round nuts are the priority food security crops under the US Presidential Feed the Future program in Africa. Thus maize is a key food security crop.

Despite the importance of maize for food security and contributing to poverty reduction across sub-Saharan Africa, maize production is constrained by complex bio- 


\section{Getachew Magnar and Bamlak Alemu}

physical, socio-economic and political factors and the remaining yield gap is huge. For instance, a considerable number of households in Ethiopia, Malawi, Zimbabwe and other sub-Saharan African countries each year suffer from malnutrition, food scarcity and hunger due to low food production (Mapila et al., 2012). The recurring episodes of food insecurity and malnutrition are a roadblock to their participation in economic development of the country, with consequences for health, education, national budgets, and social development goals. Although robust data are not available, it is evident from the donor, civil society and government priorities that food insecurity is a problem embedded in the political economy of maize that drains national resources (Harrigan, 2008; Langyintuo and Setimela, 2009).

Maize is also a political commodity. Politicians tend to allocate more funds for maize subsidies to their favourable electorates and the voters respond positively to such incentives (Mason and Ricker-Gilbert, 2013). Urban and male bias are the two major biases - towards towns rather than rural areas and towards men, not women - are principal factors in explaining Africa's food insecurity. Due to urban-bias and maize bias (Mason et al., 2011), subsidies for maize production and food distribution account for a major share of the national agricultural subsidy and underpin many investment programs and policy reforms in across Africa (Hanjra and Culas, 2011).

Climate change is a mega-scale risk, affecting food production and food security across Africa. African agriculture remains highly vulnerable to climate change and its adverse impact on food security, prices and household welfare (Jayne et al., 2006). For instance, 96\% of the cropland in SSA depend on sporadic rainfall. Maize is imported according to weather-related needs and the expected impact on maize prices, which has serious implications for the political economy of maize production and subsidies in terms of rural and urban food security. For instance, the 2002 drought-related food crisis in Zambia fuelled inflation largely driven by food prices (Jayne et al., 2006). Studies show that climate change will affect maize production across Esat, South and West African settings such as Benin (Yegbemey et al., 2013), Ghana (Tachie-Obeng et al., 2013), Kenya (Mati, 2000), South Africa (Abraha and Savage, 2006; Walker and Schulze, 2008), Zimbabwe (Nkomozepi and Chung, 2012). Alongside, a poor road infrastructure, limited access to farm credit for smallholders, high interest rates, fewer export crops and inadequate access to input and output markets are the main constraints to maize production and a more pro-poor agricultural growth process across SSA (Hanjra and Culas, 2011).

Despite lower returns to investment in maize production, smallholder subsistence farmers continue to prioritize maize production over cash crops for the market due to household level food security concerns. However, maize productivity is quite low and remaining yield gap huge. For instance, over the last two decades (1989/902009/10) maize yield has averaged 17.82 quintiles/ hectare compared to the conservative estimate of yield in farm level trails of 47 quintiles in Ethiopia. This fuels the hope that closing the maize yield gap could help improve agricultural productivity and lift millions more out of poverty across SSA. The main outstanding issues that constrain maize productivity growth include (Hanjra and Culas, 2011): poor infrastructure such as roads, bridges
Sci. Technol. Arts Res. J., July-Sep 2014, 3(3): 204-212

and transport fleet and low market participation under high transactions costs (Alene et al., 2008); inadequate storage facilities (Gitonga et al., 2013), marketing policies and institutions (Dadi et al., 1992), price regulation (Traub and Jayne, 2008), market liberalization (Pinckney, 1993; Jayne and Argwings-Kodhek, 1997), and inter-regional trade issues (Myers, 2013); poor access to microcredit; past low national funding and priority given to the agriculture sector; inadequate research support for new drought-tolerant maize varieties (Byerlee and Heisey, 1996) and for integrating the crop sector with livestock; high input prices, low input use (Sheahan et al., 2013) and low maize productivity and returns (Jayne et al., 2006); challenges of public-private interventions in maize seed industry to promote growth (Langyintuo et al., 2010), poor adoption of improved maize varieties (Feleke and Zegeye, 2006; Langyintuo and Mungoma, 2008); macroeconomic instability and high inflation etc. For instance, augmenting investments in maize-vegetable crop rotations at the expense of irrigation schemes focussed singularly on maize can boost returns to investments in irrigation and reduce government's financing burdens for maize.

Against that backdrop, this paper examines the potential for and pathways to improving maize productivity in smallholder agriculture. Empirical data and evidence on technical efficiency of smallholder maize production comes from Horo Guduru Wollega zone of the Oromia state, Ethiopia. The specific objectives of this study are to analyze the level of technical efficiency of maize producing smallholder farmers; identify the main sources of inefficiency in maize production; and recommend policy implications based on efficiency estimates to improve the technical efficiency of maize production by brining maize farmers to speed just by adopting the production practices of their better performing peers. The key argument is that brining smallholder maize farmers to speed can help contribute towards ending hunger and poverty in Ethiopia since maize is and will continue to be a key crop for food security in the region.

\section{MATERIALS AND METHODS}

This paper examines the technical efficiency of maize production in one of potential maize producing areas of Ethiopia, and seeks to address the following research questions: What is efficiency level of smallholder maize farmers? What is the scope and size of improvement in the level of technical efficiency? What are the main causes of inefficiency? What improvements in maize productivity can be achieved given the existing level of inputs and technology? And, what incentives and policies are needed for brining maize farmers to speed to help improve the technical efficiency and productivity for closing the yield gap?

This study was conducted in Horo Guduru Wollega zone of the Oromia state, Ethiopia. The capital town of the zone, Shambo city, is located $314 \mathrm{~km}$ from Addis Ababa to the western part of Ethiopia. The zone comprises nine rural districts and town. The zone covers a total land area of $8,097 \mathrm{~km}^{2}$; a total population of 641,575 of which $50.09 \%$ are male and $49.91 \%$ are female (CSA, 2011). This zone was selected for the study because of its significant contribution in maize production - maize is not only the highest productive of all cereals but also its productivity in this zone is higher than the national average (CSA, 2011). The study was conducted in the three districts of Horo Guduru Wollega zone namely, Jima Geneti, Guduru and Amuru. 


\section{Getachew Magnar and Bamlak Alemu}

The selection of respondent farmers for this study was multistage. In the first stage, three major maize producing districts of Horo Guduru Wollega zone namely Jima Geneti, Guduru and Amuru districts were purposely selected as they are the major maize producers of the zone. In the second stage we have used the sample enumeration areas selected by CSA from each district.

According to the information obtained from CSA there are four enumeration areas in each of the three districts consisting of 80 sample households each. From each of the eight selected EAs (three from each of Jima Genet and Guduru and two from Amuru) of CSA's Agricultural Sample Survey, 15 smallholder farmers were randomly selected for this study in the third stage, making up a total of 120 sample farmers in all. A detailed questionnaire was administered to household heads during the 2010 cropping season. A total of eight enumerators from CSA were involved to administer the questionnaires to the farmers.

The data was collected by interviewing the selected smallholder farmers and physically measuring fields to obtain data on crop yields and other items. Furthermore, the data obtained were recorded in various forms designed for this purpose. Instruments like, kitchen balances, scientific calculators, Global Positioning System (GPS) were used during data collection for timely and accurate data acquisition.

This study utilizes the stochastic frontier production function developed by Aigner, et al. (1977), and stated as follows for a cross-section of plots:

$$
Y_{i}=f\left(x_{i}, \beta\right) e^{\phi}, i=1, \ldots, N
$$

where $Y_{i}$ is the output produced by the $i^{\text {th }}$ farmer, $X_{i}$ is a vector of inputs used by the $i^{\text {th }}$ farmer, and $\beta$ is a vector of parameters to be estimated, where as $\phi$ is the random error term, which can be decomposed as follows:

$$
\phi_{i}=v_{i}+u_{i}
$$

$V_{i}$ in equation (5) stands for the random component representing factors that are beyond the control of the farm household, and left out explanatory variables (Aigner, et al., 1977) assumed to be independently and identically distributed (iid). As a result, $V_{i}$ is distributed $N\left(0, \sigma_{v}^{2}\right)$ and is independent of the ${ }^{U_{i}}$. On the other hand, $U_{i}$ correspond to a random variable that accounts for technical inefficiency in production and is assumed to be independently distributed, truncated at zero, and normally distributed with mean $\mu_{i}$ and variance $\left(\left|N\left(\mu_{i}, \sigma_{u}^{2}\right)\right|\right)$ where the inefficiency effects are modeled in terms of other variables, as suggested by Battese and Coelli (1995) and expressed as follows:

$u_{i}=z_{i} \delta+w_{i}$

where $z_{i}$ is a vector of explanatory variables associated with the technical inefficiency effects, $\delta$ is a vector of unknown parameters to be estimated, and $w_{i}$ represents unobservable random variables, which are assumed to be identically distributed.

The stochastic production frontier of the technically efficient farmer would represent the maximum attainable output $\left(Y_{i}^{*}\right)$ as:
Sci. Technol. Arts Res. J., July-Sep 2014, 3(3): 204-212

$$
Y_{i}^{*}=f\left(X_{i}, \beta\right) \exp \left(V_{i}\right)
$$

This can then be used to measure the technical efficiency of all other farmers, relative to this efficient farmer. Hence the technical efficiency of the $i^{\text {th }}$ farmer $\left(T E_{i}\right)$ is given by:

$$
T E_{i}=\frac{Y_{i}}{f\left(x_{i}, \beta\right) \exp \left(v_{i}\right)}
$$

where $T E_{i}$ may be defined as the capacity of a producer ith farmer to produce relative to a maximum output using a certain amount of input and available technology. From equation (5), we can observe that technical efficiency is the ratio of observed output to maximum feasible output in an environment characterized by $\exp \left(v_{i}\right)$.

The estimation of the stochastic production frontier function may be viewed as a variance decomposition model, which can be expressed as:

$\sigma^{2}=\sigma_{u}^{2}+\sigma_{v}^{2}$

Where $\sigma_{v}^{2}$ and $\sigma_{u}^{2}$ respectively are the variances of the parameters symmetric $(v)$ and one-sided (u) error terms. According to Jondrow,et al.(1982) the variance ratio parameter $\gamma$, which relates the variability due to technical inefficiency $(u)$ to the total variance $\left(\sigma^{2}\right)$ can be calculated as in equation(6) below:

$\gamma=\frac{\sigma_{u}^{2}}{\sigma^{2}}=\frac{\sigma_{u}^{2}}{\sigma_{u}^{2}+\sigma_{v}^{2}}$

As it is apparent from the discussion above, the parameter $\gamma$ is an indicator of the relative variability of the two sources of variations which takes the value between zero and one; i.e. $0 \leq \gamma \leq 1$. Hence if $\gamma$ is closer to zero the symmetric error term dominates the variation between the frontier maximum attainable level of output and the observed level of output. Or put differently, a value of $\gamma$ close to zero implies that the difference between the observed and the maximum attainable levels output is dominated by random factors outside the control of the producer where as the larger the value of $\gamma$ is the more the production is dominated by variability emanating from technical inefficiency.

\section{Empirical Specification of the Model}

The technical efficiency effect model (Coelli and Battese; 1995) in which both the stochastic frontier and factors affecting inefficiency are estimated simultaneously is specified as follows:

In Cobb-Douglas functional form:

$\ln Y_{i}=\beta_{0}+\beta_{1} \ln X_{1 i}+\beta_{2} \ln X_{2 i}+\beta_{3} \ln X_{3 i}+\beta_{4} \ln X_{4 i}+\beta_{5} \ln X_{5 i}+\beta_{6} \ln X_{6 i}$ $+v_{i}-\left(\delta_{0}+\delta_{1} z_{1 i}+\ldots+\delta_{15} z_{14 i}\right)+w_{i}$

In Translog functional form:

$\ln Y_{i}=\beta_{0}+\beta_{1} \ln X_{1 i}+\beta_{2} \ln X_{2 i}+\beta_{3} \ln X_{3 i}+\beta_{4} \ln X_{4 i}+\beta_{5} \ln X_{5 i}+\beta_{6} \ln X_{6 i}$ $+\frac{1}{2}\left[\beta_{6} \ln X_{1 i}^{2}+\beta_{7} \ln X_{2 i}^{2}+\beta_{8} \ln X_{3 i}^{2}+\beta_{9} \ln X_{4 i}^{2}+\beta_{10} \ln X_{5 i}^{2}+\beta_{11} \ln X_{6 i}^{2}\right.$

$+\beta_{12} \ln X_{1 i} X_{2 i}+\beta_{13} \ln X_{1 i} X_{3 i}+\beta_{14} \ln X_{1 i} X_{4 i}+\beta_{15} \ln X_{1 i} X_{5 i}+\beta_{16} \ln X_{1 i} X_{6 i}+\beta_{17} \ln X_{2 i} X_{3 i}$ $+\beta_{18} \ln X_{2 i} X_{4 i}+\beta_{19} \ln X_{2 i} X_{5 i}+\beta_{20} \ln X_{2 i} X_{6 i}+\beta_{21} X_{3 i} X_{4 i}+\beta_{22} X_{3 i} X_{5 i}+\beta_{23} \ln X_{3 i} X_{6 i}$ $\left.+\beta_{24} \ln X_{4 i} X_{5 i}+\beta_{25} \ln X_{4 i} X_{6 i}+\beta_{26} \ln X_{5 i} X_{6 i}\right]+v_{i}-\left(\delta_{0}+\delta_{1} z_{1 i}+\ldots+\delta_{14} z_{14 i}\right)+w$ 


\section{Getachew Magnar and Bamlak Alemu}

Where;

$\mathrm{Yi}=$ Quantity of output of Maize production in $\mathrm{kg}$

In= Natural logarithm

$\mathrm{X} 1=$ is the total number of family above sixteen years old of the ith farmer

$\mathrm{X} 2=$ Number of oxen owned by the ith farmer during the production season of 2011/12

$\mathrm{X} 3=$ Area planted with Maize crops in hectare.

$\mathrm{X} 4=$ Amount of seed used in $\mathrm{Kg}$.

$\mathrm{X} 5=$ Amount of DAP chemical fertilizer used in $\mathrm{kg}$

$X 6=$ Amount of UREA chemical fertilizer used in $\mathrm{kg}$

$\beta 1=$ Parameters to be estimated

$v 1=$ Stochastic component of error term;

$\mathrm{i}$ = number of farmer

The farm-specific inefficiency variables are:

$Z_{1}=$ is the age of the of the head of the household;

$Z_{2}=$ is the years of formal schooling of the head of the household (education).

$Z_{3}=$ Family size

$Z_{4}=$ ownership of plots of land under Maize cultivation ( $(1=$ owned, $0=$ owed $)$,

$Z_{5}=$ Extension contact /training on Maize production

$Z_{6}=$ involvement of the household in Off/non-farm activity (( $1=y e s, 0=$ otherwise),

$Z_{T}=$ Sex of the household head ( $1=$ male, $0=$ female $)$,

$Z_{8}=$ Fragmentation in number of Maize plot of land the farmer owns

$Z_{9}=$ credit $((1=$ has got, $0=$ otherwise $)$ by the ith farmer during the production year of 2011/12;

$Z_{10}=$ total livestock the farmer owns in Tropical Livestock Unit (TLU);
Sci. Technol. Arts Res. J., July-Sep 2014, 3(3): 204-212

$Z_{11}=$ Farm size which represents the total land in hectares managed by the ith farmer

$Z_{12}=$ Age square measured in years

$Z_{13}=$ Woreda Dummy (A dummy variable having a value of 1 if the household head resides in Guduru, 0 otherwise)

$Z_{14}=$ Woreda Dummy (A dummy variable having a value of 1 if the household head resides in Amuru, 0 otherwise)

$\delta i=$ parameter vector to be estimated and $\mathrm{Wi}=$ Error term.

The parameters of the stochastic production frontier model in equation (4) and those for the technical inefficiency model in equation (6) were estimated simultaneously through the maximum-likelihood estimation (MLE) method using the statistical package FRONTIER 4.1 following Coelli (1996).

\section{RESULTS AND DISCUSSION}

\section{Hypothesis testing and Model Robustness}

Before proceeding to examine the parameter estimates of the production frontier and the factors that affect the efficiency of smallholder Maize farmers, we investigate the validity of the model used for the analysis. These various tests of null hypotheses for the parameters in the frontier production functions and in the inefficiency models are performed using the generalized likelihoodratio test statistic defined by: $L R=-2\left[L L\left(H_{0}\right)-L L\left(H_{1}\right)\right]$; where $\mathrm{LL}(\mathrm{H} 0)$ and $\mathrm{LL}(\mathrm{H} 1)$ denote the values of the likelihood function under the null $\left(H_{0}\right)$ and alternative $\left(H_{1}\right)$ hypotheses, respectively As the LR test statistic follows a chi-square distribution $\left(x^{2}\right)$, with degrees of freedom equal to the number of restrictions (Coelli et al., 2005), chisquare test was carried out in maximum likelihood estimation procedure in this study. The results of various tests undertaken is presented in the table blow.

Table 1: Generalized likelihood ratio test of hypotheses for parameters of SPF and technical inefficiency factors

\begin{tabular}{|c|c|c|c|c|c|}
\hline Null hypothesis & $\begin{array}{l}\text { LL value } \\
\text { of } H_{0}\end{array}$ & $\begin{array}{l}\text { LL value } \\
\text { of } H_{1}\end{array}$ & $\begin{array}{c}\text { LR } \\
\text { Statistic* }\end{array}$ & $\begin{array}{l}\text { Critical } \\
\text { Value }^{\star \star}\end{array}$ & Decision \\
\hline $\begin{array}{l}\text { Production function is CD ((non-translog form) } \\
\left.\text { (i.e. } \mathrm{Ho}: \beta_{7}=\beta_{8}=\ldots=\beta_{27}=0\right)\end{array}$ & -112.51 & -100.17 & 24.68 & 38.93 & Accept Ho \\
\hline $\begin{array}{l}\mu \text { is half normally distributed } \\
\text { (i.e.Ho: } \mu=\mathrm{O})\end{array}$ & -91.73 & -87.51 & 8.44 & 6.63 & Reject Ho \\
\hline $\begin{array}{l}\text { Absence of inefficiency } \\
(\text { i.e.HO }: \gamma=0)\end{array}$ & -120.14 & -87.51 & 65.27 & 6.63 & Reject Ho \\
\hline $\begin{array}{l}\text { Joint efficiency effects are insignificant } \\
\left.\quad \text { (i.e. } H 0: u_{i}=\delta_{0}=\delta_{1}=\ldots=\delta_{14}=0\right)\end{array}$ & -120.14 & -87.51 & 65.27 & 30.58 & Reject Ho \\
\hline Ho: $\sum_{i}^{6} \beta_{i}=1$ & -91.53 & -87.51 & 7.84 & 6.63 & Reject Ho \\
\hline
\end{tabular}

\section{Maximum Likelihood Estimates}

The maximum likelihood estimates of the selected Cobb-Douglas type production function is given in table below. The ratios of the estimated coefficients to their corresponding standard errors which provides us t-ratios are used to test the statistical significance of the estimated parameters. The ML estimates of the $\beta$ parameters show that among $x$-variables (the conventional inputs) only the parameter for land input, Seed and DAP chemical fertilizer were found to be significant. The parameter estimate for labour, number of oxen used and UREA chemical fertilizer turned out to be insignificant. Given labour and oxen are the primary production inputs (as the production system is highly labour intensive and no other oxen competing modern inputs such as tractor is used) in the study area, the insignificance of the estimated coefficients for labour and oxen which imply that use of these inputs has no significant effect on productivity was contrary to the expectation. 
Getachew Magnar and Bamlak Alemu

Table 2: Maximum Likelihood Estimates for Parameters of SFP and Inefficiency Effects

\begin{tabular}{|c|c|c|c|}
\hline Variables & Coefficient & $\begin{array}{c}\text { Standard } \\
\text { Error }\end{array}$ & t-ratio \\
\hline \multicolumn{4}{|l|}{ Production function } \\
\hline Constant & 6.56 & 0.49 & $13.33^{* * *}$ \\
\hline Inlabor $\left(x_{1}\right)$ & -0.22 & 0.13 & -1.60 \\
\hline $\operatorname{lnoxen}\left(x_{2}\right)$ & 0.03 & 0.02 & 0.13 \\
\hline Inland $\left(x_{3}\right)$ & 0.23 & 0.12 & $1.89^{*}$ \\
\hline Inseed $\left(x_{4}\right)$ & 0.45 & 0.13 & $3.31^{* * *}$ \\
\hline $\operatorname{lnDAP}\left(x_{5}\right)$ & 0.07 & 0.02 & $3.17^{\star \star *}$ \\
\hline $\operatorname{InUREA}\left(\mathrm{x}_{6}\right)$ & -0.03 & 0.02 & -1.39 \\
\hline \multicolumn{4}{|l|}{ Inefficiency effect } \\
\hline Constant & 6.39 & 1.50 & $4.25^{\star \star \star}$ \\
\hline $\operatorname{Age}\left(Z_{1}\right)$ & -0.18 & 0.07 & $-2.39^{* *}$ \\
\hline Education $\left(Z_{2}\right)$ & -0.18 & -0.08 & $-2.64^{* * *}$ \\
\hline Family $\operatorname{size}\left(Z_{3}\right)$ & 0.04 & 0.12 & 0.32 \\
\hline Land tenancy $\left(Z_{4}\right)$ & 0.39 & 0.69 & 0.57 \\
\hline $\begin{array}{l}\text { Extension } \\
\operatorname{contact}\left(Z_{5}\right)\end{array}$ & -0.09 & 0.04 & $-2.20^{\star *}$ \\
\hline Off farm activity $\left(Z_{6}\right)$ & -2.41 & 1.01 & $-2.38^{\star *}$ \\
\hline $\operatorname{Sex}\left(Z_{7}\right)$ & -0.04 & 0.44 & -0.10 \\
\hline No of plots $\left(Z_{8}\right)$ & -1.39 & 0.26 & $-5.34^{\star * *}$ \\
\hline Credit $\left(Z_{9}\right)$ & 0.58 & 0.44 & 1.32 \\
\hline $\begin{array}{l}\text { Livestock } \\
\text { holding }\left(Z_{10}\right)\end{array}$ & -0.05 & 0.04 & -1.11 \\
\hline $\begin{array}{l}\text { Total land } \\
\text { holding }\left(Z_{11}\right)\end{array}$ & 0.21 & 0.12 & $1.69^{*}$ \\
\hline Age squared $\left(Z_{12}\right)$ & 0.002 & 0.008 & $2.57^{\star *}$ \\
\hline Guduru $\left(Z_{13}\right)$ & -0.98 & 0.63 & -1.57 \\
\hline Amuru $\left(Z_{14}\right)$ & -1.13 & 0.58 & $-1.95^{\star}$ \\
\hline$\sigma^{2}$ & 0.78 & 0.18 & $4.39^{\star \star \star}$ \\
\hline Y & 0.85 & 0.05 & $18.59^{* * *}$ \\
\hline LL & & -87.51 & \\
\hline
\end{tabular}

The estimated coefficient for land was positive, which conform to a priori expectation, and significant at $10 \%$ level. The magnitude of the coefficient of land, which is 0.23 , indicates that the Maize production is relatively more responsive to the level of cultivated land next to seed. The 0.23 elasticity of land implies that a $1 \%$ increase in cultivated land area, ceteris paribus, would lead to an increase of $0.23 \%$ in the Maize output, and vice versa. While this result emphasizes the importance of conventional inputs in such subsistence agriculture it also indicates that future growth in output from such factors is untenable given the high population growth and that the available land that can be brought under cultivation is limited.

The production elasticity with DAP chemical fertilizer is positive as expected and statistically significant at $1 \%$. The magnitude of the coefficient of seed, which is 0.45 , indicates that output in Maize production was relatively more responsive to changes in the amount of Maize seed. Thus, a $1 \%$ increase in Maize seed would induce an increase of $0.45 \%$ in the output of Maize, and vice versa.

Generally, given the specification of the Cobb-Douglas frontier model, the results show that the elasticity of mean value of farm Maize output is estimated to be an increasing function of all inputs except labour and UREA fertilizer but Maize output is more responsive to changes in Maize seed (table 2).

\section{The Variance Parameters}

The estimates for the variance parameters of $\sigma^{2}$ and $y$ are significantly different from zero at $1 \%$ level of significance. This indicates statistical corroboration of our
Sci. Technol. Arts Res. J., July-Sep 2014, 3(3): 204-212

presumption that there are differences in technical efficiency among smallholder Maize farmers in Horo Guduru Wollega zone. The share of this one- sided error term in total variance $(y)$ is $85 \%$ (table 2). This indicates that a significant portion of the variation in output for the sample farmers in Maize production from the total variation was due to technical inefficiency (i.e. about 85 percent of the variation in output was due to the inefficiency). However, 15 percent of the variation in output was due to random noise beyond the control of farmers. Examples of such random shocks include weather (poor rainfall), floods, bushfires and diseases. These values are in the ranges of the findings of many of the research works reviewed (Hasan and Islam 2010, Teshome, 2005, Khairo and Battese, 2004, Oji et al., 2007). One major random shock which was found to influence the production of Maize during the study period in our study area was the inadequate rain fall which stopped before expected time and required amount.

\section{Yield Gap due To Technical Inefficiency}

Yield gap may be defined as the difference between technically full efficient yield and observed yield. Therefore, yield gap is the amount which represents fewer yields due to technical inefficiency. From the Stochastic model defined in equation (8), TE of the ith farmer is estimated to be:

$$
T E_{i}=\frac{Y_{i}}{Y_{i}^{*}}=\frac{f(X i ; \beta) \exp (V i-U i)}{f(X i ; \beta) \exp (V i)}=\exp \left(-U_{i}\right)
$$

Then, solving for $\mathrm{Yi}^{*}$, the potential yield of each farmer is represented as:

$$
Y_{i}^{*}=\frac{Y_{i}}{T E_{i}}=f(X i ; \beta) \exp (V i)
$$

Where TEi = technical efficiency of the ith household in Maize production

$\mathrm{Yi}^{*}=$ the frontier/potential output of the ith household in Maize production, and

$\mathrm{Yi}=$ the actual/observed output of the ith household in Maize production.

Based on equation above and using the values of the actual Maize output obtained and the predicted technical efficiency indices, the potential Maize output was estimated for each household in Maize production on hectare basis. The mean result is presented in table 3 below.

Table 3: Maize Yield Gap due to Technical Inefficiency

\begin{tabular}{lcccc}
\hline \multicolumn{1}{c}{ Variable } & Mean & Std. Dev & Min & Max \\
\hline $\begin{array}{l}\text { Actual yield } \\
\text { (kg/ha) }\end{array}$ & 1238.38 & 1017.88 & 20 & 5500 \\
$\begin{array}{l}\text { Mean Technical } \\
\text { Efficiency }\end{array}$ & 0.66 & 0.24 & 0.06 & 0.92 \\
$\begin{array}{l}\text { Potential yield } \\
\text { (kg/ha) }\end{array}$ & 1675.43 & 1052.13 & 214.29 & 6043.96 \\
\begin{tabular}{l} 
Yield gap(kg/ha) \\
\hline
\end{tabular} & 437.05 & 326.63 & 46.91 & 2700 \\
\hline
\end{tabular}

It was observed that mean technical inefficiency was 34 percent which caused $437 \mathrm{~kg} / \mathrm{ha}$ yield gap of Maize on the average with mean value of the actual output and the potential output of $1234.38 \mathrm{~kg} / \mathrm{ha}$ and $1675.43 \mathrm{~kg} / \mathrm{ha}$, respectively. This shows that farmers in study area were producing on the average $437 \mathrm{~kg} / \mathrm{ha}$ lower Maize output than their potential yield. 


\section{Getachew Magnar and Bamlak Alemu}

\section{Sources of Technical Inefficiency}

Using the model specified, the study makes an attempt to investigate the determinants of technical efficiency. The coefficients of the explanatory variables in the inefficiency model are of particular interest to this study.

In explaining the influences of inefficiency variables it should be noted that in the inefficiency model, variables are included as inefficiency variables; thus a negative coefficient means an increase in efficiency and a positive effect and the positive coefficient increases inefficiency (decreases efficiency). The signs of most of the explanatory variables for the inefficiency model were as expected.

To begin with, age $\left(Z_{1}\right)$ of the household head is included to assess the effect of age on the level of technical inefficiency. It is commonly believed that age can serve as a proxy for farming experience. Thus, a farmer with older age is expected to have greater farm experience. The coefficients of age in this study was estimated to be negative as expected and statistically significant at the 5 percent level for Maize farmers which indicate that the older farmers are more technically efficient in Maize production than the younger ones. This may be due to better farm management practices developed over the years of farming experience .Moreover; farmers at older age may accumulate good command of resources like labor, oxen and farm tools that could enhance their efficiency, since better availability of farm resources enhances timely application of inputs in crop production that enhance efficiency of the farm (Mohammednur and Negash, 2010).

On the other hands we have included the variable Age square $\left(Z_{12}\right)$ to see whether age continues to have positive effect on efficiency. The result of our analysis indicates that the coefficient of age square on inefficiency is positive as of our expectation and the effect is statistically significant at $1 \%$ which suggests that farmers' efficiency increases with age of the household head up to a point and then falls down with rise in age. Although farmers become more skillful as they get older, the know-how is attenuated as they approach middle age as their physical strength begins to decline (Dolisca, et al., 2008).

Education level of farmers is a factor that the literature frequently relates to technical efficiency. The variable that has been used in this study to reflect educational level is the years of schooling of sample farmers. The coefficient of education $\left(Z_{2}\right)$ variable is estimated to be negative as expected and statistically significant at 5 per cent level for Maize farmers which indicate that farmers with greater years of formal education tend to be more efficient technically in Maize production probably due to their enhanced ability to acquire technical knowledge, which make them produce closer to the frontier output.

The theoretical justification for considering agricultural extension in technical efficiency studies is due to its effect on the acquisition of information. Increased agricultural extension activities are expected to increase farmers technical efficiency by lowering farmers cost of information. The coefficient of extension $\operatorname{contact}\left(Z_{5}\right)$ in this study is negative as expected and significant, suggesting that such contact increases farm efficiency because farmers are able to use modern techniques of Maize
Sci. Technol. Arts Res. J., July-Sep 2014, 3(3): 204-212

farming involving land preparation, planting, application of agro-chemicals (for example, fertilizer) and harvesting. The explanation is that farmers who have adequate extension contact avail themselves of modern agricultural technology for input mobilization, input use and disease control, which enables them to reduce technical inefficiency. Thus increasing the frequency of development agent visits is of paramount importance to provide effective agricultural extension services in the area.

Off-Farm $\left(Z_{6}\right)$ is an inefficiency variable measured based on whether or not the farmer is engaged in off/nonfarm activities during the main season. A number of studies conducted revealed that off/non- farm activities have a systematic effect on the technical efficiency of the farmers. It will have a negative relation with the technical efficiency if the farmer is always out of the farming activity for the search of additional income from these off/nonfarm activities. On the other hand, it will affect the technical efficiency positively for the reason that the income obtained from such off/non- farm activities could be used for the purchase of agricultural inputs, and augment financing of household expenditures which would otherwise, put pressure on on-farm income. The result of this study revealed that engagement in off/nonfarm activities are found to significantly and positively affect technical efficiency of the farmers. The possible explanation is that it would assist the farmers to supplement other costs associated with their living, perhaps. The finding is consistent with the findings of Khairo and Battese (2004) who argue that presumably farmers having greater off-farm income might be more efficient as they gain experience because off-farm income might be a proxy for agricultural credit. Nevertheless the finding of this study is contradictory to the findings of Gebreegziabher, et al. (2004), Alemu, et al.(2009), Dolisca and Jolly (2008) who argue that increases in nonfarm work are accompanied by a relocation of time away from farm- related activities.

Fragmentation $\left(Z_{8}\right)$ represents the number of plots of land on which the farmer has grown Maize during the production season in which this study was carried out. It was hypothesized that a farmer with more number of Maize plots is more inefficient than a farmer with more consolidated area. The reason might be that fragmented land is difficult for effective management of the crop and hence a farmer having more plots is expected to loss time by moving between plots. Contrary to our expectation, however, the coefficient of fragmentation variable is estimated to be negative and statistically significant at $1 \%$ level suggesting that a farmer with more number of plots is technically more efficient in producing Maize as compared to its counterpart in the study area. The reason is perhaps as the number of plots operated by the farmer increases, the farmer will be able to distribute labor resources (which in our case is found to be negatively related to Maize production possibly due to over utilization) for different activities. Moreover, it might be used as one of the risk minimization strategies of farmers. Farmers may be benefited from fragmented Maize plots in that different plots may represent the reduced risk that different plots provide if the plots are located sufficiently distributed, such that farmers face different degrees of weather-induced variations such as floods and mineral content on the different plots. 


\section{Getachew Magnar and Bamlak Alemu}

The variable total land holding $\left(Z_{11}\right)$ is aimed at capturing the effect of scale production on the technical efficiency of the farm. In this study the coefficient of this variable is positive meeting our expectation and statistically significant in the technical inefficiency model for Maize production which implied that technical inefficiency increases with the increase in total land holding. That is, farmers with smaller farms are technically more efficient than farmers with larger operations. This can be explained by the fact that increased farm size diminishes the aptness of input use leading to decline in technical efficiency. Or as the farm size increases the managing ability of the farmer decreases given the level of technology which adversely affects technical efficiency. The inverse relationship between total land size and technical efficiency corroborates the findings of Msuya, et al. (2008), Aye and Mungatana (2010) and Carter (1984). This finding calls attention to the need to make policies that favor small scale farmers as they are the backbone of agricultural growth in developing countries more generally and in Ethiopia in particular.

\section{Technical Efficiency Scores}

The average estimated technical efficiency for smallholder Maize producers in the study area ranges from 0.06 to 0.92 with a mean technical efficiency of 0.66 suggesting that there exists a huge potential to increase per hectare Maize output. This value indicates that most farmers are not technically inefficient in producing Maize crop in the study area in that on average farmers can boost the output they are getting by 34 percent without increasing the existing level of inputs. Conversely, farmers on average could decrease inputs (labor, oxen power, land and seed) by 34 percent to get the output they are currently getting if they use inputs efficiently. It is also evident from table 4 below that $46(38.33 \%)$ Maize farmers out of 120 are operating below the Mean technical efficiency of $66 \%$ and only $12(10 \%)$ farmers are operating above $90 \%$ level of technical efficiency. This implies that a great proportion of small holder Maize farmers in the study area faced sever technical inefficiency problems.

The mean level of efficiency found in this study is low but comparable to those from other African countries. For instance, Alemu, et al. (2009) found the mean technical efficiency of East Gojam of Ethiopia to be 75.68 percent, Rahman, et al. (2009) found mean efficiency levels of about $69.6 \%$ among crop production in Lafia local government area of Nasarawa state, Nigeria while Oluwatayo, et al. (2008) found mean efficiency levels of about $68 \%$ among Maize farmers in rural Nigeria.

Table 4: Frequency distributions of TE estimates for maize farmers

\begin{tabular}{lcc}
\hline $\begin{array}{c}\text { Technical Efficiency } \\
\text { Levels }\end{array}$ & $\begin{array}{c}\text { Number of } \\
\text { Farmers }\end{array}$ & $\begin{array}{c}\text { Percentage } \\
\text { of Total }\end{array}$ \\
\hline$<0.50$ & 25 & 20.83 \\
$0.50-0.60$ & 13 & 10.83 \\
$0.60-0.70$ & 17 & 14.17 \\
$0.70-0.80$ & 20 & 16.67 \\
$0.80-0.90$ & 33 & 27.5 \\
$>0.90$ & 12 & 10.00 \\
\hline Mean TE & $\mathbf{0 . 6 6}$ & \\
Minimum TE & $\mathbf{0 . 0 6}$ & \\
Maximum TE & $\mathbf{0 . 9 2}$ & \\
$<\mathbf{0 . 6 6}$ & $\mathbf{4 6}$ & $\mathbf{3 8 . 3 3}$ \\
\hline
\end{tabular}

Sci. Technol. Arts Res. J., July-Sep 2014, 3(3): 204-212

The distribution of the technical efficiency in table above clearly shows that the technical efficiency is skewed heavily in the 0.80 and 0.90 range, representing $27.5 \%$ of the sample farmers. The wide variation in technical efficiency estimates is an indication that most of the farmers are still using their resources inefficiently in the production process and there still exists a wide room for improving Maize production through improving the current level of technical efficiency contrasting the Schultz's hypothesis.

However, it should be noticed that when we say Maize production can be increased without additional investment on new technology, we are not suggesting that new technologies are not required, rather we mean that as long as the existing technology is not fully utilized it is more cost effective to improve Maize production through improving technical efficiency of farmers than through investing in new technologies.

\section{CONCLUSIONS}

This study estimated the levels of technical efficiency in maize production among smallholder farmers in Horo Guduru Wollega zone of Oromia regional state, Ethiopia. The data were obtained from a random sample of 120 maize farmers from three purposively selected potential maize producers of the zone, over the 2011/12 cropping year and analyzed using a Cobb-Douglass stochastic production frontier function.

The results show that maize producers in our study area are technically inefficient and average farmer achieves only $66 \%$ efficiency and lies $26 \%$ below the efficiency levels achieved by best performing farmers in the sample. This means that substantial scope exists for improving maize productivity and enhancing food security by just adoption of the management practices of best performing farmers. The analysis also reveals that age, the educational level of the farmer, land fragmentation, extension contact, involvement in off-farm activity and total land holding of the farmer are the major socioeconomic variables significantly influencing farmers' technical efficiency.

The estimated stochastic production frontier model indicates that DAP chemical fertilizer was a key input in improving maize productivity although its response is one of the lowest perhaps, due to the low application level of the input. This implies that there is a need to increase the current level of chemical fertilizer use along with good farm management.

The result of this study further reveals that the contribution of Maize seed in increasing Maize production However, at present, improved seeds are provided mainly by the government, cooperative unions and very few other private seed companies but at high price for small-holder farmers who are usually resource constrained suggesting that incentivizing the private sector to further participate in seed production and supply is vital.

The negative elasticity of Maize output with respect to labour may possibly be explained by the fact that farmers with surplus labour force are likely to use excessive family labour. This might be due to limited opportunities for income generating activities outside agriculture especially in rural areas. This calls for better utilization of available 


\section{Getachew Magnar and Bamlak Alemu}

human resource in rural areas by creating alternative income generating activities outside maize farming.

Likewise, though the result is not statistically significant, the negative elasticity for urea chemical fertilizer may be due to the fact that it is used in abundance compared to poorer rainfall of the production season when yields are lower. This implies that policies interventions should envisage a package approach whereby the application of urea chemical fertilizer should be accompanied by other complimentary inputs such as irrigation where possible- that can reduce the output shocks (which risk farmers during seasons of low rainfall).

Results of the study further indicate the presence of technical inefficiency, which captures about $85 \%$ of the gap between the observed and best practice output. The estimated technical efficiency for smallholder maize producers in the study area ranges from $6 \%$ to $92 \%$ with a mean technical efficiency of $66 \%$ suggesting that there is ample scope to increase maize output with current production technology.

The low level of technical efficiency clearly shows that the attention of policy makers should be geared towards alleviation of the existing level of food insufficiency and extreme poverty by improving agricultural production not only through the introduction and diffusion of yield enhancing externally supplied modern inputs but also improving the existing level of efficiency. The argument here is that improvements in the use of improved technologies are expensive, require relatively longer time to achieve and farmers have serious financial problems. Consequently, any endeavor designed to reduce technical inefficiency of farmers is expected to generate additional output with current technologies.

Age, used as a proxy for experience, showed a positive and significant relationship with efficiency. This may be due to experience learnt over the years of farming activity. Therefore mechanisms should be devised to encourage farmers with little experience to work with the experienced ones or train them. This could be done via the Farmer Field School (FFS) in which the experienced farmers are trained and let to diffuse their accumulated practices to the youngsters with less experience.

Education of the farmers was also found to reduce the production inefficiency. The farmers may be encouraged to improve their level of education by establishing adult literacy program within the reach of farmers. Thus, while substantiating the on-going government policy on education, it is one of the priority issues to further strengthen the efforts on expanding education to explore and develop human resources of farms in a bid to helping them enhance their efficiency.

Nevertheless farmers may not be educated in a short period of time. Here extension service which is found to positively and significantly influence technical efficiency, as a supplementary to education has a positive role to play. Hence, organizing frequent trainings for development agents and supervisors about existing and newly developed improved technologies and new methods of agricultural practices is worthwhile. This is expected to develop the confidence of the agents to pass on appropriate and useful information to farmers.
Sci. Technol. Arts Res. J., July-Sep 2014, 3(3): 204-212

As credit was not found to add to efficiency, strengthening the existing off-farm employment opportunities will also greatly help ease farmers' liquidity constraints and enhance the financial ability of smallholder farmers to acquire external inputs. Therefore, improving farmers' involvement in off-farm income generating activities can be an appropriate policy instrument to improve the technical efficiency of maize production in the study area.

\section{REFERENCES}

Abraha, M.G. and Savage, M.J. (2006) 'Potential impacts of climate change on the grain yield of maize for the midlands of KwaZulu-Natal, South Africa', Agriculture, Ecosystems and Environment 115(1-4): 150-160.

Aigner Dennis, L.K. (1977). Formulation and Estimation of Stochastic Frontier Production Function models. Journal of Econometrics 6: 21-37.

Alemu, B.A., Nuppenau, E.A., and Boland, H. (2009). Technical Efficiency of Farming Systems across Agroecological Zones in Ethiopia: An Application of Stochastic Frontier Analysis. Agricultural Journal 4(4).

Alene, A.D., Manyong, V.M., Omanya, G., Mignouna, H.D., Bokanga, M. and Odhiambo, G (2008). Small Holder market participation under transaction costs: Maize supply and fertilizer demand in kenya. Food Policy 33(4): 318-328.

Aye, G.C. and Mungatana, E.D. (2010). Technical efficiency of traditional and hybrid maize farmers in Nigeria: Comparison of alternative approaches. African Journal of Agricultural Research 5(21): 2909-2917.

Battese, G.E., and Coelli, T.J. (1995). A Model for Technical Inefficiency Effects in a Stochastic Frontier Production Function for Panel Data. Empirical Economics 20: 325332.

Byerlee, D. and Heisey, P.W. (1996). Past and potential impacts of maize research in subSaharan Africa: a critical assessment. Food Policy 21(3): 255-277.

Carter, M.R. (1984). Identification of the Inverse relationship between farm size and productivity:An emperical Analysis of peasant Agricultural production. Oxford Economic papers, New Series 36(1): 131-145.

Coelli, T.J. (1996). A Guide to FRONTIER Version 4.1: Acomputer program for Stochastic Frontier production and cost Function Estimation. University of New England,Center for Efficiency and Productivity Analysis working papers, Department of Econometrics, Australia.

Coelli, T.J., Rao, D.P., O'Donnell, C.J., and Battese, G.E. (2005). An introduction to Efficiency and Productivity Analysis. (second, Ed.) New York,NY 10013 , USA: Springer Science+Business Media,Inc.

CSA. (2011). Federal Democratic Republic of Ethiopia Central statistical Agency Statistical Abstract. Addis Ababa,Ethiopia.

Dadi, L., Negassa, A. and Franzel, S. (1992). Marketing maize and tef in western Ethiopia: Implications for policies following market liberalization'. Food Policy 17(3): 201213.

Dolisca, F. and Jolly, C. M. (2008). Technical Efficiency of Traditional and Non-Traditional Crop Production: A Case Study from Haiti. World Journal of Agricultural Sciences 4 (4): 416-426. 


\section{Getachew Magnar and Bamlak Alemu}

Feleke, S. and Zegeye, T. (2006). Adoption of improved maize varieties in Southern Ethiopia: Factors and strategy options. Food Policy 31(5): 442-457.

Gebreegziabher, Z., Oskam, A., and Woldehanna, T. (2004). Technical Efficiency of Peasant Farmers in northern Ethiopia: A stochastic Frontier Approach.

Gitonga, Z.M., De Groote, H., Kassie, M. and Tefera, T. (2013). Impact of metal silos on households' maize storage, storage losses and food security: An application of a propensity score matching. Food Policy 43(0): 44-55.

Hasan, M.K., and Islam, F.M. (2010). Technical Inefficiency of Wheat Production in some selected areas of Bangladesh. Bangladesh Journal of Agricultural Research 35(1): 101-112.

Harrigan, J. (2008). Food insecurity, poverty and the Malawian Starter Pack: Fresh start or false start? Food Policy 33(3): 237-249.

Jayne, T.S. and Argwings-Kodhek, G. (1997). Consumer response to maize market liberalization in urban Kenya', Food Policy 22(5): 447-458.

Jondrow, J., Lovell, C.K., Materov, I.S., and Schmidt, P. (1981). On the Estimation of Technical Inefficiency in the Stochastic production function Model. Journal of Econometrics 19: 233-238.

Khairo, S.A. and Battese, G.E. (2004). A study of technical inefficiencies of Maize farmers within and outside the New Agricultural Extension programm in the Harari region of Ethiopia. Addis Ababa, Ethiopia.

Langyintuo, A.S. and Mungoma, C. (2008). The effect of household wealth on the adaption of improved maize varieties in Zambia. Food Policy 33(6): 550-559.

Langyintuo, A.S. and Setimela, P. (2009). Assessing the effectiveness of a technical assistance program: The case of maize seed relief to vulnerable households in Zimbabwe', Food Policy 34(4): 377-387.

Mapila, M.A.T.J., Njuki, J., Delve, R.J., Zingore, S. and Matibini, J. (2012). Determinants of fertiliser use by smallholder maize farmers in the Chinyanja Triangle in Malawi, Mozambique and Zambia. Agrekon 51(1): 21-41.

Mason, N.M., Jayne, T.S., Chapoto, A. and Donovan, C. (2011). Putting the $2007 / 2008$ global food crisis in longerterm perspective: Trends in staple food affordability in urban Zambia and Kenya. Food Policy 36(3): 350-367.

Mason, N.M. and Ricker-Gilbert, J. (2013). Disrupting Demand for Commercial Seed: Input Subsidies in Malawi and Zambia. World Development 45(0): 75-91.

Mati, B. M. (2000). The influence of climate change on maize production in the semi-humid-semi-arid areas of Kenya', Journal of Arid Environments 46(4): 333-344.

Myers, R.J. (2013). Evaluating the effectiveness of interregional trade and storage in Malawi's private sector maize markets', Food Policy 41(0): 75-84.

Mohammednur, Y. and Negash, Z. (2010). Effect of Microfinance Participation on Farmers' Technical Efficiency: Panel Evidence from Tigray, Northern Ethiopia. Mekelle University, Department of Economics, Mekele, Ethiopia.
Sci. Technol. Arts Res. J., July-Sep 2014, 3(3): 204-212

Msuya, E., and Ashimogo, G. (2005). Estimation of Technical Efficiency in Tanzanian Sugarcane Production: A Case Study of Mtibwa Sugar EstateOutgrowers Scheme. Sokoine University of Agriculture, Morogoro, Tanzania.

Munir Hanjra and Richard J. Culas (2011). The political economy of maize production and poverty reduction Zambia: Analysis of last 50 years. Journal of Asian and African Studies 46(6): 546-566.

NEPAD. (2003). Comprehensive Africa Agricultural Development Programme. Pretoria.

Nkomozepi, T. and Chung, S.O. (2012). Assessing the trends and uncertainty of maize net irrigation water requirement estimated from climate change projections for Zimbabwe. Agricultural Water Management 111(0): 60-67.

Oji, U.O. and Chukhuma, A.A. (2007). Technical efficiency of smallscale Poultry-Egg production in Nigeria:Emperical study of poultry farmers in Imo state,Nigeria. Research Journal of Poultry Sciences 1(3-4): 16-21.

Oluwatayo, I.B., Sekumade, A.B., and Adesoji, S.A. (2008). Resource use Efficiency of Maize farmers in rural Nigeria:Evidence from Ekiti state. World Journal of Agricultural Sciences 4(1): 91-99.

Pinckney, T.C. (1993). Is market liberalization compatible with food security?: Storage, trade and price policies for maize in Southern Africa', Food Policy 18(4): 325-333.

SADC (2003). Southern African Development Community. 2003. Regional Indicative Strategic Development Plan.

Schultz, T.W. (1964). Transforming Traditional Agricultural. Chicago: University of Chicago Press.

Sheahan, M., Black, R. and Jayne, T. S. (2013). Are Kenyan farmers under-utilizing fertilizer? Implications for input intensification strategies and research. Food Policy 41(0): $39-52$.

Teshome, K. (2005). Technical Efficiency of Maize production: A case of smallholder farmers in Assosa Woreda. M.Sc thesis, Alemaya University, Agricultural Economics, Alemaya, Ethiopia.

Traub, L.N. and Jayne, T.S. (2008). The effects of price deregulation on maize marketing margins in South Africa. Food Policy 33(3): 224-236.

Walker, N.J. and Schulze, R.E. (2008). Climate change impacts on agro-ecosystem sustainability across three climate regions in the maize belt of South Africa. Agriculture, Ecosystems and Environment 124(1-2): 114124.

UNCTAD. (2002). Investment and Innovation Policy Review in Ethiopia. New York and Geneva: United Nations.

UNDP. (2002). African-Asian Agriculture against AIDS. A Joint Publication of FAO and UNDP.

Yegbemey, R.N., Yabi, J.A., Tovignan, S.D., Gantoli, G. and Haroll Kokoye, S.E. (2013). Farmers' decisions to adapt to climate change under various property rights: A case study of maize farming in northern Benin (West Africa). Land Use Policy 34: 168-175. 